\title{
Microbial Recovery of Gold from Mahd El-Dahab Mine Kingdom of Saudi Arabia
}

\author{
Nora Shenouda Gad, Mahmoud H. Shalaby \\ Nuclear Materials Authority of Egypt, Cairo, Egypt \\ Email: norashenouda@yahoo.com
}

Received 1 June 2015; accepted 18 June 2015; published 25 June 2015

Copyright (C) 2015 by authors and OALib.

This work is licensed under the Creative Commons Attribution International License (CC BY).

http://creativecommons.org/licenses/by/4.0/

(c) (i) Open Access

\begin{abstract}
This paper considers the use of the yeast Saccharomyces cerevisiae as a biosorbent for the recovery of gold from Mahd El-Dahhab gold mine in Kingdom of Saudi Arabia. Gold is a noble metal which was seldom used in electroplating, hydrogenation catalyst, etc. Heterogeneous composition of samples and low concentration offer renewed interest in the selective extraction of gold using various extractants. In the present work, Saccharomyces cerevisiae, is used to study the preconcentration of gold, which in the original sample was $0.44 \mathrm{ppm}$, while after treatment with Saccharomyces cerevisiae it raises to $7 \mathrm{ppm}$ with efficiency reaching about $1600 \%$.
\end{abstract}

\section{Keywords}

Recovery, Saccharomyces cerevisiea, Gold

Subject Areas: Biotechnology, Microbiology

\section{Introduction}

Gold, the noblest one of metals, has been used by man for more than 5000 years. Its extreme softness or malleability, and resistance to tarnish (oxidation), led to its earliest use in art and currency. Gold is the metal of choice for jewelers, and is often used in dentistry. Gold has been successfully used in many modern technological applications. It is used as the electrical contacts of computer chips. Minute quantities of gold (less than 3 micrograms) are vaporized to mirror lens surfaces [1].

Minor concentrations of gold occur in most natural substances. In seawater, for example, there is approximately 0.012 parts per billion (ppb) of gold and in fresh water it is slightly higher at $0.02 \mathrm{ppb}$. Its average concentration in the Earth's crust or lithosphere is approximately $5 \mathrm{ppb}$, and in certain sedimentary rocks it may achieve concentrations of up to $2100 \mathrm{ppb}$ or 2.1 parts per million (ppm). 


\subsection{Geology of Mahd El Dahab}

Mahd El Dahab is an epithermal, low sulphidation, adularia type, polymetallic deposit. The total production has been estimated at over 100 tons of gold [2]. The reserves before the last stage of exploitation were around 1.2 Mt at $24 \mathrm{~g} / \mathrm{t} \mathrm{Au}, 92 \mathrm{~g} / \mathrm{t} \mathrm{Ag}, 0.65 \% \mathrm{Cu}$ and $3.11 \% \mathrm{Zn}$.

Systematic rock geochemistry over a $50 \mathrm{~m} \times 50 \mathrm{~m}$ grid discovered new reserves [3]. The meta-volcanics are rich in quartz veins. The polymetallic mineralization of chalcopyrite, sphalerite, galena, gold and silver tellurides, and rare electrum occurs in a dense vein network. the quartz veins contain cockade breccias , felsic agglomerate and crystal tuffites. The mineralization is older than $709 \mathrm{Ma}$, the age of the intersecting dikes [4]. Zinc grades increase to the North and at depth but Au grades decrease commensurately. In Nov 1999, the remaining $0.65 \mathrm{Mt}$ were estimated to contain $12 \mathrm{~g} / \mathrm{t}$ Au and 3.11\% Zn.

Four successive alteration stages are observed: early alteration with quartz, sericite, pyrite; an intermediate stage with chlorite, sericite, microcline, sphalerite, pyrite; the gold bearing stage with quartz, chlorite, sphalerite, galena, pyrite, gold, tellurides, and accessory siderite-calcite-hematite and a final stage with quartz, calcite, and barite. Minor (apparently) gold indications are known from near Mahd Adh Dhahab, as Lahuf [5] (Figure 1).

\subsection{Previous Work of Leaching}

Extraction of gold from solutions is under active investigation by using a variety of physical, chemical, and biological processes. Recovery of ionic gold from dilute solutions usually involves either precipitation by zinc dust, carbon adsorption, solvent extraction, or ion exchange resins. All of these are of low selectivity and comparatively expensive [6] [7]. Chemical methods for the recovery of gold from ores include cyanidation and thiourea leaching, which present environmental and health risks [8] [9].

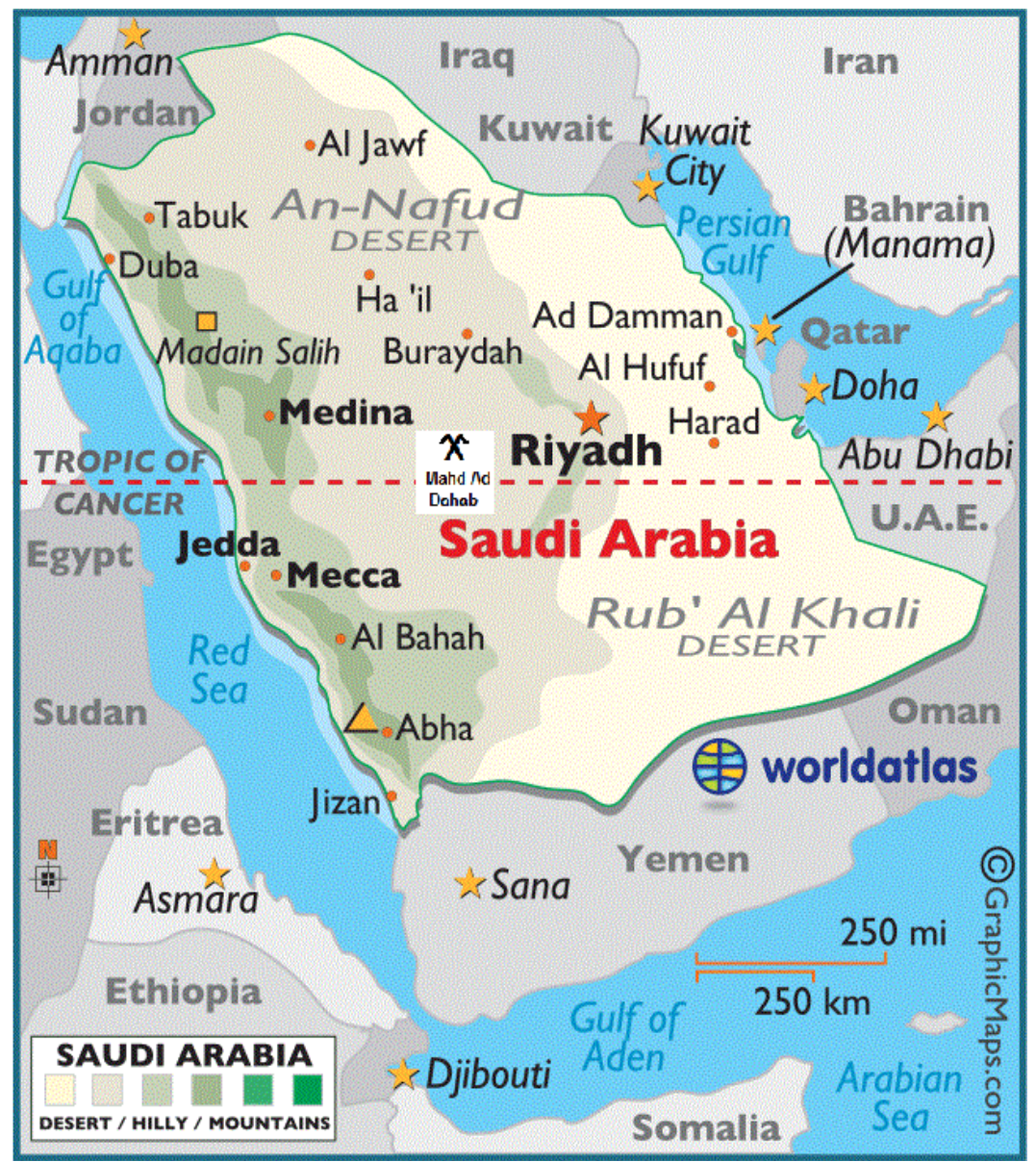

Figure 1. Location map of Mahd El Dahab, Kingdom of Saudi Arabia. 
Biorecovery of dissolved gold from solution presents fewer environmental risks than chemical methods, and is documented for microorganisms [7] [10] [11], algae [7] [9], yeast [12] and fungi [7] [13]-[15].

The ore contained $8.2 \% \mathrm{Fe}, 0.78 \% \mathrm{Cu}, 0.88 \% \mathrm{As}$, and $0.035 \%$ with pyrite, hematite, arsenopyrite, and chalcopyrite as the main metal-bearing minerals. Initial gold recovery by conventional cyanidation on a crushed ore sample was 54\%; concentration by flotation improved recovery to 56\%. Concentrated samples (17.0 g Au/ton) were leached in reactors at $\mathrm{pH}$ 1.8. In the presence of bacteria, all dissolved iron was presented as ferric ion; gold recovery by cyanidation increased from $13 \%$ for the initial concentrate to $97 \%$ after 10 days of bacterial leaching. To further increase gold recovery, flotation tailings were submitted to cyanidation [16].

Algal cells, alive or dead, rapidly accumulated $\mathrm{Au}^{3+}$ and begin to reduce it to $\mathrm{Au}^{0}$ and $\mathrm{Au}^{+}$within 2 days [17]. Four species of ground dried seaweeds (Sargassum sp., Gracilaria sp., Eisenia sp., and Ulva sp.) [18] treated seaweeds removed $75 \%$ - 90\% of the gold within 60 min at $\mathrm{pH} 2$ from solutions containing $5.0 \mathrm{mg} \mathrm{Au}{ }^{3+} / \mathrm{L}$.

Gold $\left(\mathrm{Au}^{3+}\right)$ can be sequestered from acid solutions by dead biomass of a brown alga, Sargassum natans (Linnaeus), and deposited in its elemental form, $\mathrm{Au}^{0}$.

The cell wall of Sargassum was the major locale for gold deposition, with carbonyl groups $(\mathrm{C}=\mathrm{O})$ playing a major role in binding, and N-containing groups have lesser role. Like activated carbon, the biomass of Sargassum natans is extremely porous, reportedly more than most biomaterials, and accounts, in part for its ability to accumulate gold [19].

The bioreduction of $\mathrm{Au}^{+3}$ to $\mathrm{Au}^{0}$ using biomass of the brown alga Fucus vesiculosus was investigated. The recovery and reduction process took place in two stages with an optimum $\mathrm{pH}$ range of 4 - 9 with a maximum uptake obtained at $\mathrm{pH} 7$ [20].

The effects of ionic gold on Saccharomyces cerevisiae, extension of preincubation time of yeast cells in goldcontaining medium resulted in a decreasing proton efflux rate and colloidal phase formation in the cell suspensions. The time between gold addition and the beginning of colloidal phase formation depended on the gold concentration used. Both Ca and Mg enhanced the inhibitory effect of gold on the yeast cells with Ca showing a stronger inhibitory effect than Mg [21].

\section{Methodology}

- Mahd El Dahab sampling:

Sample in this work was kindly obtained from Mahd El Dahab mine, Kingdom of Saudi Arabia.

- The organisms used in this work.

Saccharomyces cerevisiae used in this work was provided by EL-Hwamdiyah Company of Yeast and Sugar,

Giza, Egypt. It is cultivated in (glucose-peptone-yeast extracts broth) medium which composition is

Yeast extracts $\quad 3 \mathrm{~g} \mathrm{~L}$

Peptone $3 \mathrm{~g} \mathrm{~L}$

Glucose $\quad 10 \mathrm{~g} \mathrm{~L}$

Agar $\quad 15 \mathrm{~g} \mathrm{~L}$

Dist. water $\quad 1000 \mathrm{ml}$.

The obtained glucose-peptone-yeast-extracts agar media was melted and poured into Petri dishes and then left to solidify, by using a sterile inoculation needle a loop full of one of colonies was taken and streaked on the surface of the solidified agar plates, followed by incubation for 72 hours at $30^{\circ} \mathrm{C}$. Sub culture was prepared by addition of pure Saccharomyces colonies on slants of glucose-peptone yeast agar.

- Preparation of liquid media:

An amount of $100 \mathrm{ml}$ of glucose-peptone yeast extract previously prepared medium were added to 100 gm of Mahd Ad Dahab gold sample and let for incubation for 10 day at $30^{\circ} \mathrm{C}$. All flasks were sealed with removable cotton. Temperature was kept in the incubator at $28^{\circ} \mathrm{C}-30^{\circ} \mathrm{C}$ during the experiment.

After separation the media, the result of Mahd Ad Dahab gold sample was dried and weighted then subjected to different analysis to identify the elements and groups which were affected by Saccharomyces cerevisiae.

- Sample analysis

The collected sample was identified through four collaborative techniques.

\subsection{Fire Assay}

Fire assay has been in use for thousands of years and still stands the test of time as the standard method to value 
noble metals. A lot of attention are given to "micron gold" or "colloidal gold". A cold hard fact of this type of gold requires a lot of material to make even one ounce. Generally, much more ore than an independent operator is equipped to move. No machine, recovery process, or chemical method will produce any gold if there are not enough values to collect it from the ore.

The ore must, in all case, be reduced to a state of fine powder so as to pass through at least a 60 mesh sieve. The metallic residues they must be carefully collected and cupelled separately with lead.

Pyritic ores: they are treated either by preliminary roasting at a low temperature until sweep and then treated just as the ores with basic gangues, or they may be fused at once with a heavy charge of red lead, and little or no charcoal.

$\begin{array}{ll}\text { A suitable charge would be: } \\ \text { Ore } & 50 \text { gram } \\ \text { Red lead } & 60 \text { gram } \\ \text { Borax } & 20 \text { gram } \\ \text { Sodium carbonate } & 40 \text { gram }\end{array}$

A little sand may be added if silica is not already presented, and care must be taken to thoroughly saturate the charge with metallic iron. The precautions already referred to as to fritting of the charge, and the treatment of the button must be carefully absorbed. The sample was treated with fire assay before and after treatment with Saccharomyces cerevisiae

\subsection{Environmental Scanning Electron Microscope}

Environmental scanning electron microscope (ESEM), Philips XL 30 was applied for brief qualitative investigation of minerals in each sample for quick semi quantitative of the obtained products under the usual conditions at low vacuum. And voltage from $5-30 \mathrm{KV}$, the back scatter electron detector (BSE), and occasionally gas scatter electron detector (GSE) were used for photomicrographs. The attached unit of energy dispersive X-ray (EDX) was used to obtain the semi quantitative chemical analysis.

\subsection{Infrared Spectroscopy}

The samples are subjected to Infrared spectroscopy in order to determine the function groups of the samples. The used instrument is Naxux 670 FTIR, Company name (Nicollet) USA. The range of spectrum is usually performed from 4000 to $400 \mathrm{Cm}^{-1}$, with resolution $4 \mathrm{Cm}^{-1}$.

\subsection{X-Ray Diffraction}

XRD was used to identify the unknown minerals using instrument Philips PW3710/31 diffract meter with automatic sample changer PW1775, (21 positions) scintillation counter, Cu-target tube and Ni filter at $40 \mathrm{KV}$ and MA. This instrument is connected to a computer system using X-40 diffraction program and ASTM cards for mineral identification in NMA.

\section{Result and Discussion}

The Saccharomyces sp. is one of the best studied and commercially exploited of all microorganisms [22]. Saccharomyces cerevisiae is a by-product of large scale fermentation and its annual production is in the order of millions of tons, thus it has the potential to provide large quantities of cheap biomass [23]. Yeasts require a minimum number of inorganic ions in micro and mill molar.

The roles of the ions in yeast cells are twofold:

1) Enzymatic functioning as part of the catalytic centre of an enzymes, as activators of enzyme activity and as physiological regulators. Zinc, cobalt, manganese and copper are common in catalytic centres; magnesium acts as an enzyme activator and potassium commonly functions as a metal co-enzyme;

2) A structural function. Potassium and magnesium have a role in neutralizing electrostatic interactions between cellular anionic units of polyphosphates, DNA, RNA and proteins [24]. $\mathrm{Ca}^{+}, \mathrm{Mi}^{+}$and $\mathrm{Zn}^{+}$are often complexes to membrane phospholipids and cell wall phosphomannans.

The presence of cations in yeast is significant with respect to its exploitation as a metal biosorbent. Yeast cells require metals for normal metabolic processes and readily accumulate a range of metals. The second point re- 
lates to the delicate intracellular ionic balance, with imbalances being reflected as alterations in metabolic processes and growth characteristics. Exposure of yeast from malt fermentation to high levels of metals in a bioremediation system would possibly lead to cell death and further metal removal would be by metabolism independent mechanisms.

The cell wall and plasma membrane are the most important components of the yeast cell in metal removal from aqueous solutions. The cell wall maintains structure and rigidity and is permeable to solutes smaller than 600 Dalton. It serves as the initial contact point and provides the negative functional groups for cation binding. The yeast cell wall consists of an intermesh of polysaccharide microfibrils in a matrix of various polysaccharides, proteins and lipids. The major constituent ( $\sim 60 \%)$ of the cell wall is the polysaccharide mixture of glucans, phosphomannans and chitin [25] [26].

Chemical and enzymatic isolation of the cell wall components of Saccharomyces cerevisiae indicates metal binding to each of the cell wall components. The isolated components accumulate greater quantities of cations than intact cells, with the outer mannan-protein layer being identified as more important for metal binding than the inner chitin layer [27].

In contrast to bacteria with a single plasma membrane, Saccharomyces cerevisiae cells contain a number of specialized membranes. Most important to metal transport are the outer membrane separating the cell components from the external medium and the vacuolar membrane which compartmentalizes different metabolically important compounds [28]. The plasma membrane is composed of a lipid bilayer containing assymetrically located proteins. These proteins mediate the selective uptake and/or secretion of solutes.

Transport of solutes through the membrane is mediated by primary and secondary transport proteins. Primary transport is the active process in which chemical energy is converted to electrochemical energy [29].

Fire assay is used for the determination of gold before and after treatment with Saccharomyces cerevisiae the original gold content in the sample is $0.44 \mathrm{ppm}$ and reach a higher value $7 \mathrm{ppm}$ as shown in Table 1 and Figure 2. BSE image of ESEM shows several images before starting treatment and Figure 3 shows mineralized

Table 1. Fire assay analysis for gold.

\begin{tabular}{cc}
\hline Au Before (ppm) & Au After (ppm) \\
\hline 0.44 & 7 \\
\hline
\end{tabular}

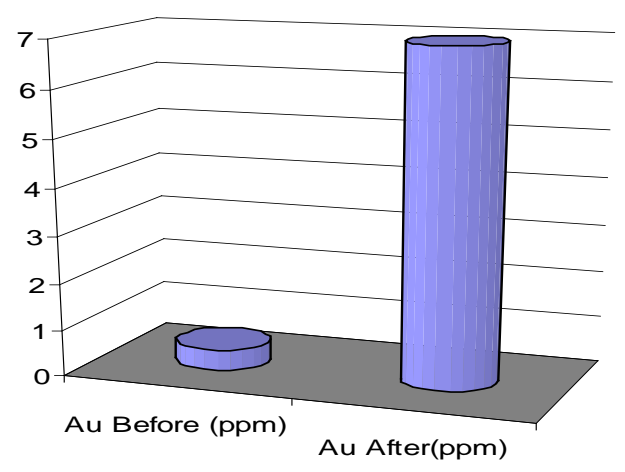

Figure 2. Fire assay analysis for gold.

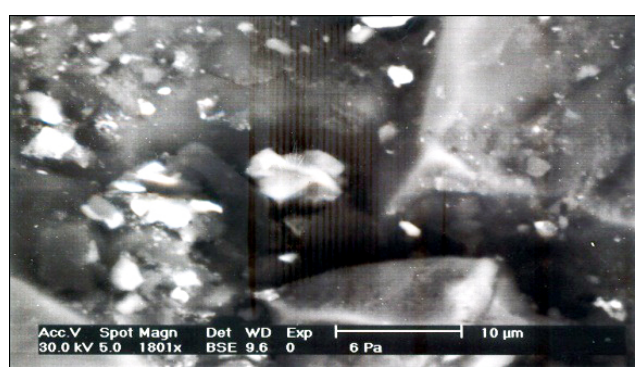

Figure 3. BSE image for mineralized volcanic rocks shows gold and sulphides. 
volcanic rocks with gold and sulphides, while Figure 4 shows gold crystal with chalcopyrite, and elongated gold crystal with high brightness in Figure 5. After treatment with Saccharomyces cerevisiae gold crystal appears associated with chalcopyrite in Figure 6 while gold crystal only in Figure 7, finally Figure 8 shows image showing a large agglomeration mode up of individual micro particles of gold due to microbial activity.

The cell wall of Saccharomyces cerevisiae was the major locale for gold accumulation. Treatment with Saccharomyces cerevisiae on Mahd Ad Dahab gold sample in infra red instrument notified the presence of functional group $\mathrm{OH}$, Ch aliphatic, Co acidic and C-O-C, after action with Saccharomyces cerevisiae we notice the appearance of two function groups ( $\mathrm{CO}$ imide $\& \mathrm{SO}_{2}$ ), with the disappearance of $\mathrm{C}=\mathrm{C}$ after microbial action as appeared in Figure 9. Using XRD analysis data is to determine the difference of the mineralized rock before and after treatment. Chalcopyrite appears alone before using microbial activity and after treatment it shows low amount of chalcopyrite and quartz. The decrease of chalcopyrite amount in the analyzed sample indicated that gold was included in this minerals and was extracted by the action of Saccharomyces cerevisiae. The chalcopyrite has been completely dissolved with the appearance of quartz in low concentration as shown in Figure 10.

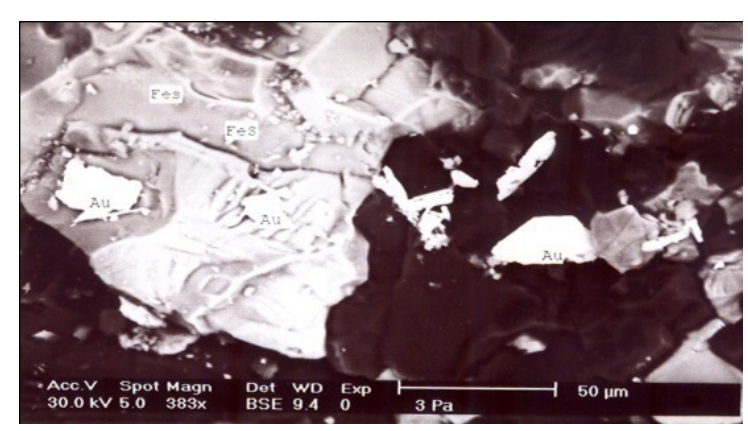

Figure 4. BSE image shows gold crystal with chalcopyrite.

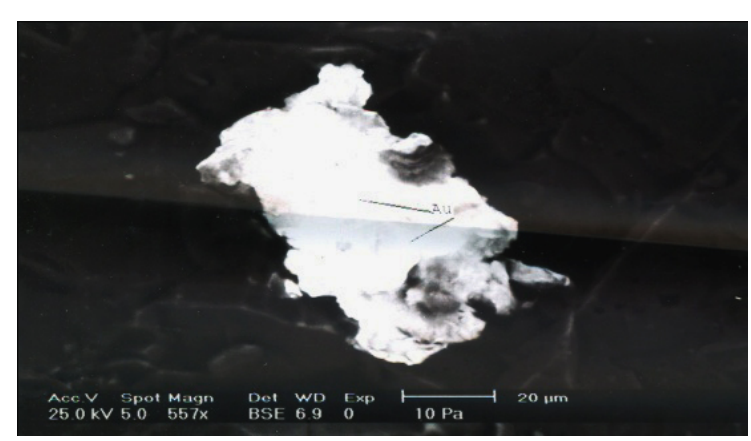

Figure 5. BSE image shows elongated gold crystal with high brightness.

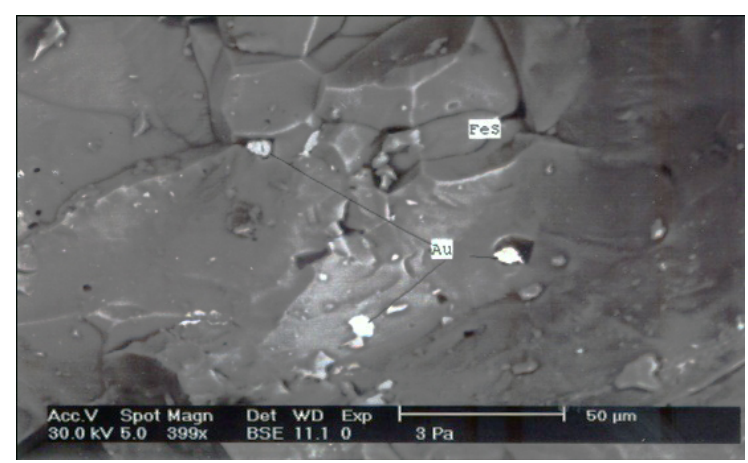

Figure 6. BSE image for gold crystal associated with chalcopyrite. 


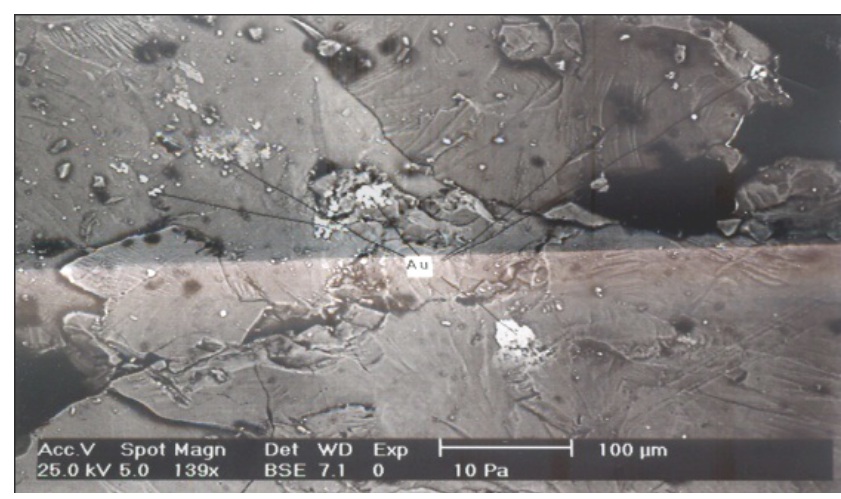

Figure 7. BSE image for gold crystal.
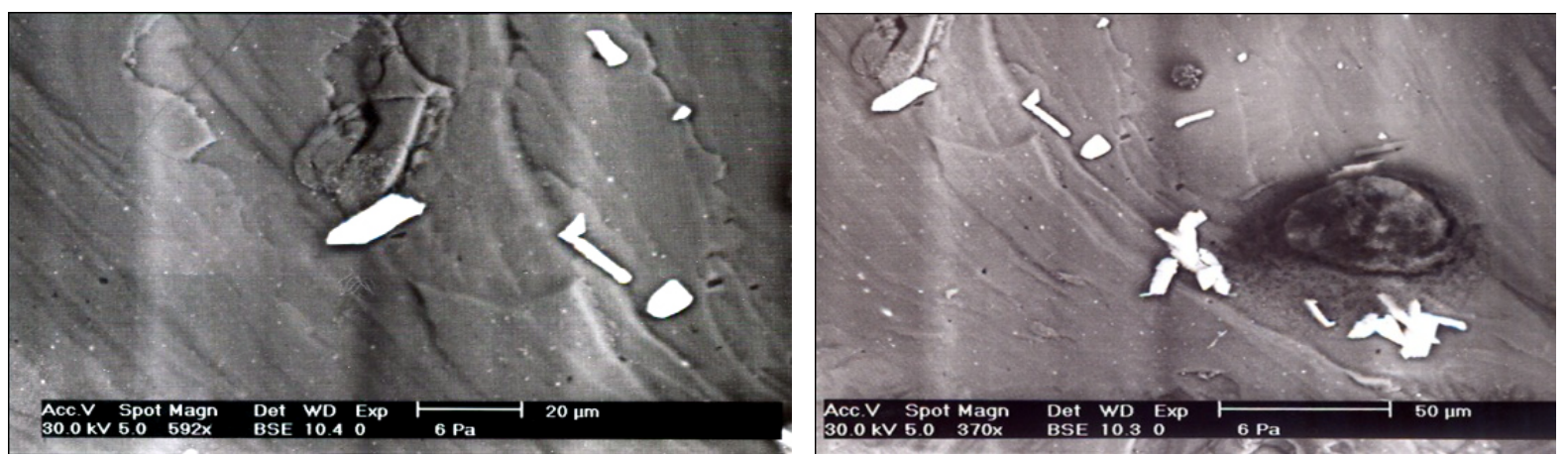

Figure 8. ESEM image shows a large agglomeration mode up of individual micro particles of gold.

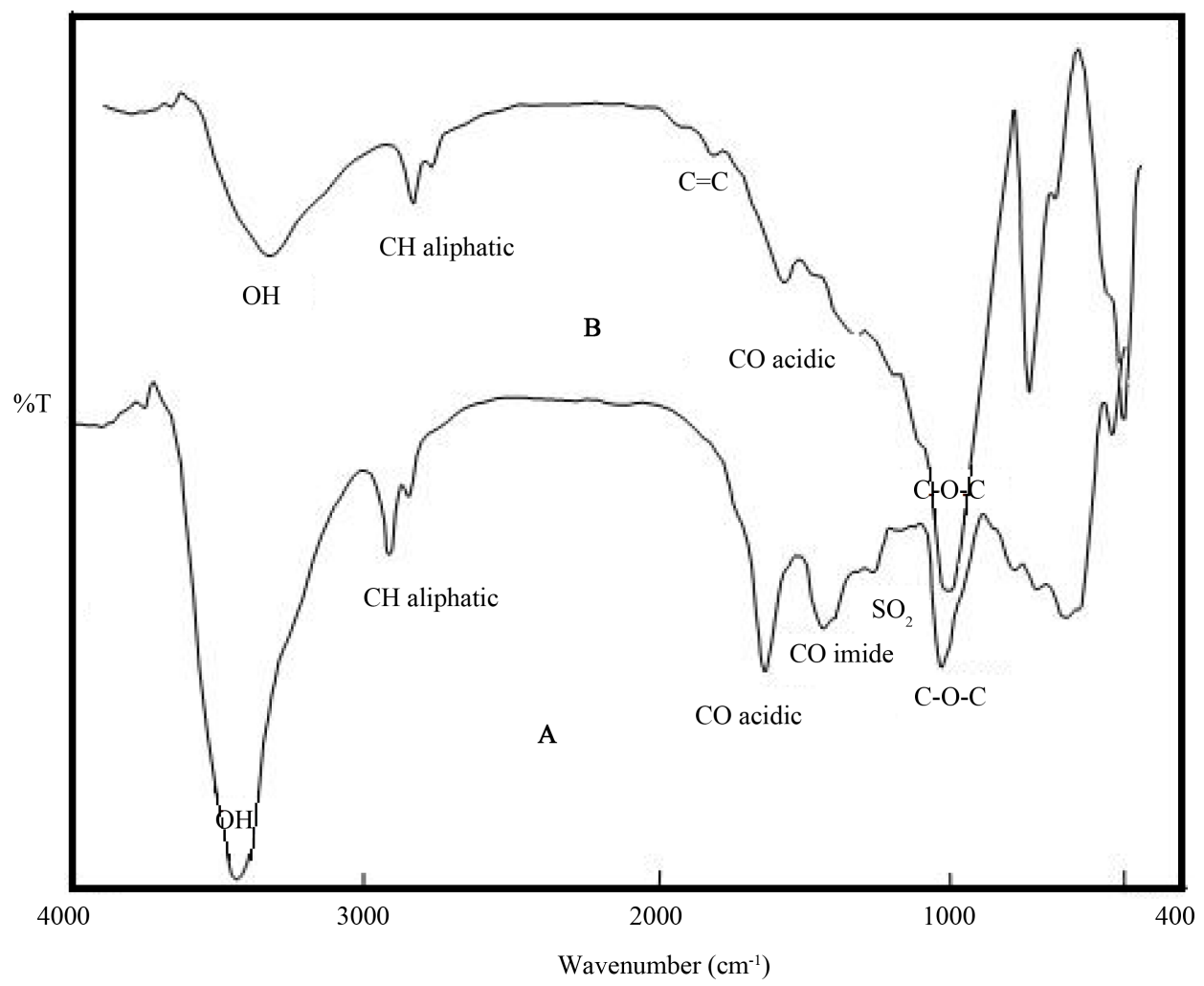

Figure 9. Infra red analysis of Mahd Ad Dahab Gold before and after treatment. A = after, B = before. 


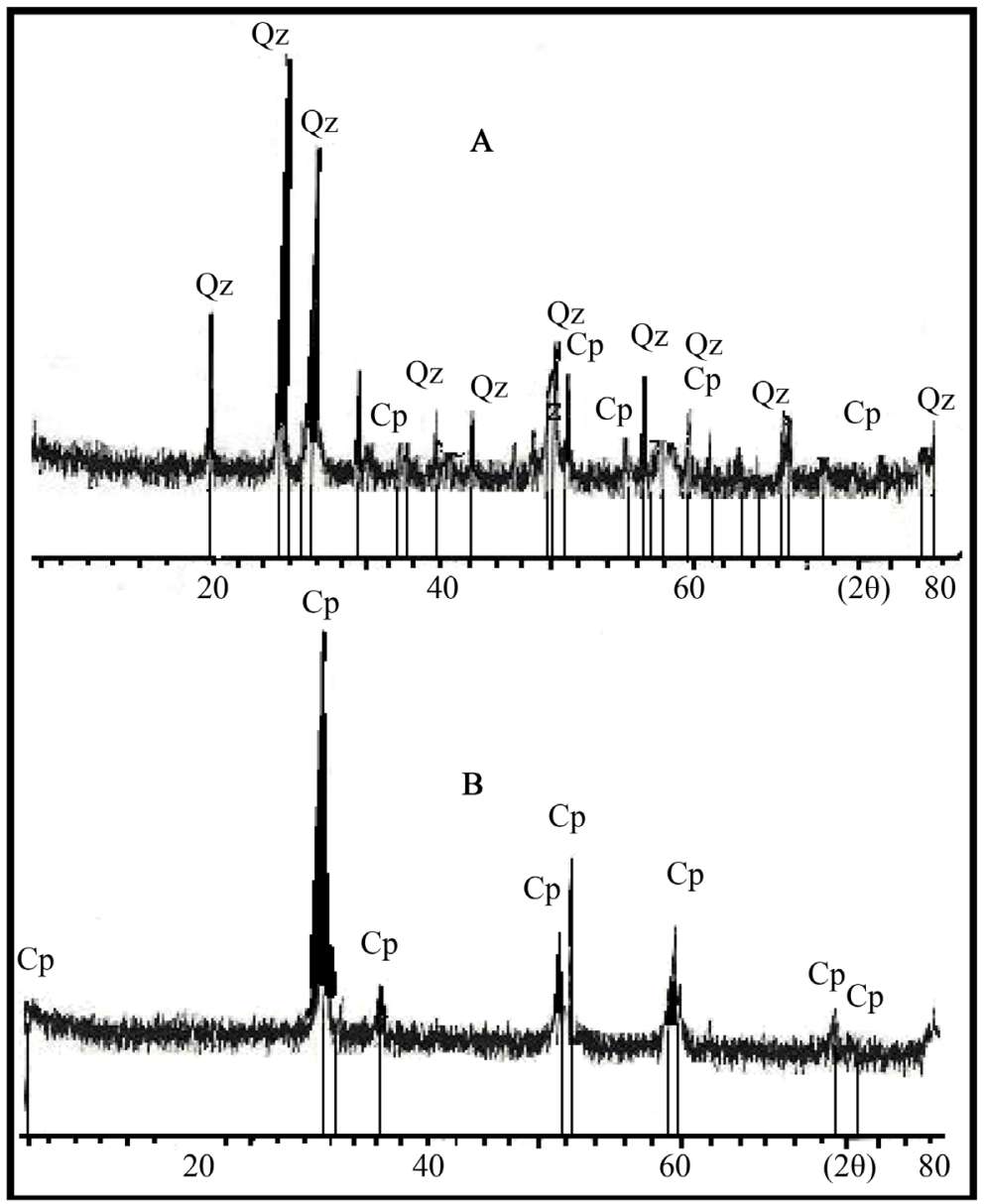

Figure 10. XRD pattern of Mahd Ad Dahab gold sample before and after treatment. $\mathrm{A}=$ after, $\mathrm{B}=$ before.

\section{Conclusion}

Gold is a noble metal, the term "noble metal" means that the metal will not oxidize or react with most acids. Mahd adh Dhabab is one of the largest gold mine in the Arabian world, the estimated reserve are around 1.2 MT of gold with an average grade of $24 \mathrm{~g} / \mathrm{t}$. The sample provided from the mine is taken at one of the richest part of the mine, it is noticed that the abundance of chalcopyrite in the original sample decreases after treatment in big amount. Saccharomyces cerevisiae action on the sample leads to recovery of gold from $0.44 \mathrm{ppm}$ to $7 \mathrm{ppm}$ with efficiency reaching about $1600 \%$ from the original sample.

\section{References}

[1] Boyle, R.W. (1979) The Geochemistry of Gold and Its Deposits. Geological Survey of Canada, Bulletin No. 280 , 583 p.

[2] Doebrich, J.L. (1999) Mahd Adh Dhahab Gold Deposit, Kingdom of Saudi Arabia. IUGS/UNESCO Deposit Modeling Workshop Field Trip Guidebook, 1-23.

[3] Roberts, R.J. (1960) Alignment of Mining Districts in North-Central Nevada. U.S. Geological Survey Professional Paper 400-B, B17-B19.

[4] Huckerby, J.A., Moore, J. and Davis, G.R. (1983) Tectonic Control of Mineralization at Mahd Adh Dhahab Gold Mine, Western Saudi Arabia, Transactions of the Institution of Mining and Metallurgy Section B. Applied Earth Science, 92, B171-B182.

[5] Khudeira, B. (1999) Mahd Ad Dahab, Ashgill Australia, Internal Report.

[6] Suyama, K., Fukazawa, Y. and Suzumura, H. (1996) Biosorption of Precious Metal Ions by Chicken Feather. Applied Biochemistry and Biotechnology, 57/58, 67-74. http://dx.doi.org/10.1007/978-1-4612-0223-3 7 
[7] Niu, H. and Volesky, B. (1999) Characteristics of Gold Biosorption from Cyanide Solution. Journal of Chemical Technology and Biotechnology, 74, 778-784. http://dx.doi.org/10.1002/(SICI)1097-4660(199908)74:8<778::AID-JCTB99>3.0.CO;2-Q

[8] Eisler, R., Clark Jr., D.R., Wiemeyer, S.N. and Henny, C.J. (1999) Sodium Cyanide Hazards to Fish and Other Wildlife from Gold Mining Operations. In: Azcue, J.M., Ed., Environmental Impacts of Mining Activities: Emphasis on Mitigation and Remedial Measures, Springer-Verlag, Berlin, 55-67. http://dx.doi.org/10.1007/978-3-642-59891-3_5

[9] Gardea-Toniesdey, J.L., Tiemann, K.J., Gamez, G., Dokken, K., Cano-Aguilera, I., Furenlid, L.R. and Renner, M.W. (2000) Reduction and accumulation of gold(III) by Medicago sativa Alfalfa Biomass: X-Ray Absorption, Spectroscopy, $\mathrm{pH}$, and Temperature Dependence. Environment Science and Technology, 34, 4392-4396. http://dx.doi.org/10.1021/es991325m

[10] Puddephatt, R.J. (1993) The Chemistry of Gold Mineralogical Controls on the Bacterial Oxidation of Refractory Barberton Gold Ores. Microbiol Soc Microbiol Rev, II, 197.

[11] Kashefi, K., Tor, J.M., Nevin, K.P. and Lovley, D.R. (2001) Reductive Precipitation of Gold by Dissimilatory Fe(III)Reducing Bacteria and Archaea. Applied and Environmental Microbiology, 67, 3275-3279. http://dx.doi.org/10.1128/AEM.67.7.3275-3279.2001

[12] Savvaidis, I. (1998) Recovery of Gold from Thiourea Solutions Using Microorganisms. Biometals, 11, 145-151. http://dx.doi.org/10.1023/A:1009234113485

[13] Niu, H. and Volesky, B. (2000) Gold-Cyanide Biosorption with L-Cysteine. Journal of Chemical Technology \& Biotechnology, 75, 436-442. http://dx.doi.org/10.1002/1097-4660(200006)75:6<436::AID-JCTB243>3.0.CO;2-O

[14] Gomes, N.C.M. and Linardi, V.R. (1996) Removal of Gold, Silver and Copper by Living and Nonliving Fungi from Leach Liquor Obtained from the Gold Mining Industry. Revista de Microbiologia, 27, 218-222.

[15] Ting, Y.P. and Mitlal, A.K. (1999) An Evaluation of Equilibrium and Kinetic Models for Gold Biosorption. Resource and Environmental Biology, 2, 311-326.

[16] Maturana, H.R. and Varela, F.J. (1987) The Tree on Knowledge: The Biological Roots of Human Understanding. New Science Library, Shambhala, London.

[17] Robinson, M.G., Brown, L.N. and Hall, B.D. (1997) Effect of Gold(III) on the Fouling Diatom Amphora Coffeaeformis: Uptake, Toxicity and Interactions with Copper. Biofouling, 11, 59-79. http://dx.doi.org/10.1080/08927019709378320

[18] Zhao, Y.F., Hao, Y. and Ramelow, G.J. (1994) Evaluation of Treatment Techniques for Increasing the Uptake of Metal Ions from Solution by Nonliving Seaweed Algal Biomass. Environmental Monitoring and Assessment, 33, 61-70. http://dx.doi.org/10.1007/bf00546662

[19] Kuyucak, N. and Volesky, B. (1990) Biosorption by Algal Biomass, Ch .2.4. In: Volesky, B., Ed., Biosorption of Heavy Metals, CRC Press, Boca Raton, 7-44.

[20] Mata, Y.N., Torres, E., Blazquez, M.L., Ballester, A., González, F. and Munoz, J.A. (2009) Gold(III) Biosorption and Bioreduction with the Brown Alga Fucus vesiculosus. Journal of Hazardous Materials, 166, 612-618. http://dx.doi.org/10.1016/j.jhazmat.2008.11.064

[21] Karamushka, V.I. and Gadd, G.M. (1999) Interaction of Saccharomyces cerevisiae with Gold: Toxicity and Accumulation. Biometals, 12, 289-294. http://dx.doi.org/10.1023/A:1009210101628

[22] Stewart and Russell (1985) Saccharomyces cerevisiae Final Risk Assessment. Journal of General Microbiology, 131, 1217-1221.

[23] Blackwell, R.D., Miniard, P.W. and Engel, J.F. (2002) Consumer Behavior. 9th Edition, Harcourt, Orlando.

[24] Jones, R. and Greenfield, P. (1984) A Review of Yeast Ionic Nutrition-Growth and Fermentation Requirements. Process Biochemistry, 19, 48-60.

[25] Northcote, D.H. and Horne, R.W. (1952) The Chemical Composition and Structure of the Yeast Cell Wall. Biochemical Journal, 51, 232-236.

[26] McMurrough, I. and Bartnicki-Garcia, S. (1971) Inhibition and Activation of Chitin Synthesis by Mucor rouxii Cell Extracts. The Journal of Biological Chemistry, 246, 4008-4016.

[27] Brady, K.T., Killeen, T., Saladin, M.E., Dansin, B. and Becker, S. (1994) Comorbid Substance Abuse and Posttraumatic Stress Disorder: Characteristics of Women in Treatment. American Journal on Addictions, 3,160-164.

[28] Okorokov, L.A., Lichkol, P. and Kulaevi, S. (1980) Vacuoles: Main Compartments of Potassium Magnesium and Phosphate Ions in Saccharomyces carlsbergensis. Journal of Bacteriology, 144, 661-672.

[29] Gadd, G.M. and Laurence, O.S. (1996) Demonstration of High-Affinity $\mathrm{Mn}^{2+}$ Uptake in Saccharomyces cerevisiae: Specificity and Kinetics. Microbiology, 142, 1159-1167. 